\title{
Învățământ prin ultrasonografie în Europa anului 2013
}

În paleta manifestărilor ştiințifice de ultrasonografie ale ulltimilor ani, un loc de frunte l-au ocupat acelea cu caracter formativ, de învățământ prin ultrasonografie. Cursurile europene de ultrasonografie - Euroson school - cursuri de tradiție, de peste 10 ani în organizarea EFSUMB şi a societăților naționale de ultrasonografie, au ajuns în 2013 la un numar de 9, printre care problematica CEUS, într-o continuă efervescență, a fost prezentă în tematica a 5 cursuri. Niciodată o tehnică ultrasonografică nouă nu a revoluționat într-atat aplicațiile diagnostice şi terapeutice. Astfel după cursul cu aplicații de contrast din 21-22 februarie, organizat la Viena şi cel de ultrasonografie intervențională, organizat în 10-12 aprilie la Berlin, ar urma cursul centrat pe produşii de contrast şi ecoendoscopie în gastroenterologie, organizat la Bergen, Norvegia, în 22-23 iunie, şi mai multe cursuri de toamnă - 11-12 septembrie, Copenhaga, curs cu aceeași tematică, extinsă şi la aplicațiile interventionale, 23-24 septembrie, curs de aplicații ale ultrasonografiei în oncologie, organizat la Paris, 18-19 octombrie, curs de ultrasonografie abdominală, la Kosice, Slovacia şi 2 cursuri CEUS - 24-27 octombrie, la Hanovra şi 15-16 noiembrie, la Roma.

În afara primelor aplicații ale produşilor de contrast în caracterizarea patologiei focale, în special hepatice, în prezent țintele s-au diversificat enorm, de la monitorizarea chimioterapiei la ficatul transplantat, sau de la ultrasonografia 3D cu produşi de contrast sau tratamentul cancerului pancreatic sau renal, la patologia inflamatorie intestinală sau patologia genitală.

Aflată la cea de a XVI-a ediție Conferința Natională de Ultrasonografie, în organiza- rea SRUMB, în perioada 30 mai - 1 iunie la Oradea, este precedată de un curs european endorsed, de asemenea în problematica a două tehnici noi, produşii de contrast şi elastografia. De astă dată cursurile sunt extinse asupra dirijării si monitorizării procedurilor intervenționale, aplicațiilor vasculare abdominale, cuantificării informației şi utilității în evaluarea eficienței terapiei sau noilor aplicații ale elastografiei.

În 2012, cu prilejul Congresului de ultrasonografie de la Cluj au fost inaugurate două secțiuni - educația medicală folosind ultrasonografia şi cursurile de ultrasonografie pentru studenții la medicină, continuate şi în acest an, în cadrul conferinței de la Oradea. Astfel la prima dintre ele sunt abordate problemele utilizării simulatoarelor pentru deprinderea abilităților practice, educația în ultrasonografie folosind cercetarea şi progresele tehnologice sau internetul, sau educația medicală a studentilor şi rezidenților prin ultrasonografie. În acest an a fost incheiat proiectul E-EDUMED LLP/LdV/TOI / RO/2010/006 intitulat Centrul Educational e-learning în Medicină (http://www.e-edumed.ro), înscris în rândul programelor de EMCD prin internet, on-line, interactive, atât prin consultanța cu tutori de program acreditați, cu asigurarea unei testări finale securizate, cât şi prin suportul informațional oferit, cu link-uri şi portaluri specifice.

Platforma e-learning construită în cadrul proiectului include: cursuri on line asincrone - PPT şi note de curs, lecții multimedia, cursuri on-line sincrone cursuri implementate în cadrul claselor virtuale şi lecțiilor multimedia. Toate cursurile cuprinse pe platformă pot fi uti-

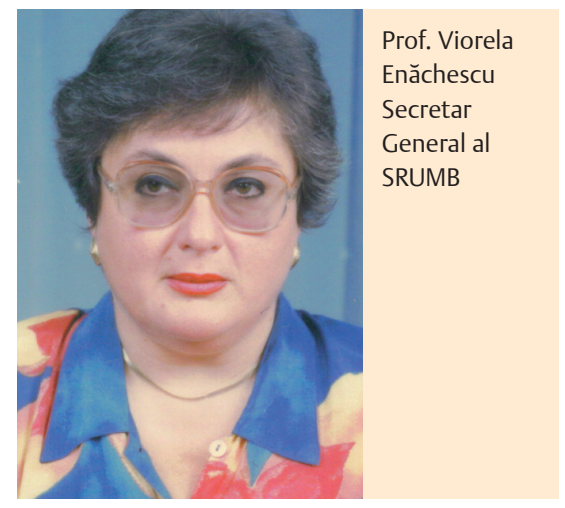

lizate în continuare de serii de cursanți, cu nivel de bază, în acest an fiind propuse perioadele aprilie-iunie şi octombrie-decembrie. Cursurile pentru studenții la medicină abordează atât aplicațiile ultrasonografiei abdominale, sau reno-urinare, cât şi cele ale ecocardiografiei, ecografiei vasculare sau aplicațiile metodelor Doppler. Prin toate aceste sesiuni de învățământ în ultrasonografie, SRUMB se înscrie printre primele țări europene cu preocupări susținute în învațamântul în şi prin ultrasonografie.

De altfel în ultimii ani EFSUMB a dezvoltat un portal educațional de ultrasonografie, o carte electronică de ultrasonografie şi a postat principalele ghiduri, protocoale şi recomandări de practică a ultrasonografiei.

În perioada 9-12 octombrie 2013, la Centrul Internațional al Congreselor din Stuttgart, Germania, va fi organizat cel de-al 25-lea Congres european al EFSUMB - Euroson 2013, care în afara cursurilor precongres, a sesiunilor ştiințifice paralele, va dezvolta secțiunile de învățământ în ultrasonografie prin sesiunile de poster electronic şi demonstrații practice hands-on. 